\title{
Selective copper(II) acetate and potassium iodide catalyzed oxidation of aminals to dihydroquinazoline and quinazolinone alkaloids
}

\author{
Matthew T. Richers, Chenfei Zhao and Daniel Seidel ${ }^{*}$
}

\author{
Full Research Paper \\ Address: \\ Department of Chemistry and Chemical Biology, Rutgers, The State \\ University of New Jersey, Piscataway, New Jersey 08854, USA \\ Email: \\ Daniel Seidel ${ }^{*}$ - seidel@rutchem.rutgers.edu \\ * Corresponding author \\ Keywords: \\ aminal; copper; oxygen; tert-butylhydroperoxide; quinazoline alkaloid
}

Open Access
Beilstein J. Org. Chem. 2013, 9, 1194-1201.

doi:10.3762/bjoc. 9.135

Received: 27 March 2013

Accepted: 28 May 2013

Published: 20 June 2013

This article is part of the Thematic Series "Transition-metal and organocatalysis in natural product synthesis".

Guest Editors: D. Y.-K. Chen and D. Ma

(C) 2013 Richers et al; licensee Beilstein-Institut.

License and terms: see end of document.

\begin{abstract} number of quinazoline alkaloid natural products and their analogues.

\section{Introduction}

Quinazoline alkaloids are a class of naturally occurring compounds with a range of medicinal properties and have been indicated for use as bronchodilators, vasodilators, anti-inflammatory agents and acetylcholinesterase inhibitors [1-5]. Many of the plants these products have been isolated from, such as Adhatoda vasica, Peganum harmala and Evodia rutaecarpa, have been used in folk medicine for centuries [6-9]. Since the original isolation of vasicine (1, Figure 1) in 1888 [10], the biological properties of this class of alkaloids have been extensively studied.
\end{abstract}

Copper(II) acetate/acetic acid/ $\mathrm{O}_{2}$ and potassium iodide/tert-butylhydroperoxide systems are shown to affect the selective oxidation of ring-fused aminals to dihydroquinazolines and quinazolinones, respectively. These methods enable the facile preparation of a

A number of synthetic strategies have been employed to gain access to quinazoline alkaloids [5,11-26]. Perhaps the most common method involves the condensation of an orthoaminobenzoic ester with a lactam promoted by phosphoryl chloride, known as the Niementowski reaction [3,27-30] (Figure 2). The availability, or lack thereof, of the corresponding lactam can determine the length and efficiency of the route. Access to the sometimes more biologically active dihydroquinazolines, such as deoxyvasicine (2), from quinazolinones requires a subsequent reduction of the amide. In 2008 , our group reported the syntheses of deoxyvasicinone (4) and rutaecarpine (6) by the potassium permanganate promoted oxidation of aminals, which in turn were obtained from the condensation of ortho-aminobenzaldehydes and simple secondary amines $[31,32]$. A number of these aminal precursors were 
<smiles>[R]C1CCN2Cc3ccccc3N=C12</smiles>

vasicine $\mathrm{R}=\mathrm{OH}, 1$ deoxyvasicine $\mathrm{R}=\mathrm{H}, 2$<smiles>[R]C1CCn2c1nc1ccccc1c2=O</smiles>

vasicinone $\mathrm{R}=\mathrm{OH}, 3$ deoxyvasicinone $\mathrm{R}=\mathrm{H}, \mathbf{4}$<smiles>O=c1c2ccccc2nc2n1CCCC2</smiles>

mackinazolinone, 5<smiles>O=c1c2ccccc2nc2n1CCc1c-2[nH]c2ccccc12</smiles>

rutaecarpine, 6
Figure 1: Examples of naturally occurring quinazoline alkaloids

prepared in generally good to excellent yields with the scope encompassing various cyclic amines and substituents on the aminobenzaldehyde aryl ring. Since then, we have demonstrated that the reaction can be run on a multigram scale [33] and have shown that dihydroquinazolines vasicine (1) and deoxyvasicine (2) can be synthesized from their corresponding aminals by using an iodine-promoted oxidation [34]. While resulting in good yields, these oxidations have the drawback of requiring large amounts of a strong oxidant for the permanganate oxidation and the necessity of stoichiometric $n$-butyllithium for the iodine reaction.
The conversion of the aminals formed from the condensation of aminobenzaldehydes and secondary amines to the corresponding dihydroquinazoline and quinazolinone structures under mild and catalytic conditions would be preferable to using harsh oxidants and strong bases. Han et al. have recently shown the ability of copper salts, in conjunction with oxygen, to catalyze oxidations of 2-substituted tetrahydroquinazoline aminals to quinazolines [35] (Figure 2). In addition, Reddy and co-workers have developed a catalytic system in which 2,3-substituted tetrahydroquinazoline aminals are converted to quinazolinones using tert-butylhydroperoxide (TBHP) and catalytic potassium iodide [36,37]. While these examples deal with the oxidation of bicyclic aminals, we were interested in developing methods to create dihydroquinazoline and quinazolinone alkaloids from ring-fused aminals. Here we present catalytic methods for the synthesis of both these compound classes from aminals using $\mathrm{Cu}(\mathrm{OAc})_{2} / \mathrm{O}_{2} / \mathrm{AcOH}$ and $\mathrm{KI} / \mathrm{TBHP}$ systems, respectively.

\section{Results and Discussion Copper-catalyzed oxidations of aminals to dihydroquinazolines}

Copper-catalyzed oxidation reactions have received a great deal of interest in recent years [38-44]. Han's copper-catalyzed method for the synthesis of aminals to quinazolines results in high yields [35], but the process is not applicable to monooxidation as dihydroquinazolines are not isolated as products in these reactions. We set out to develop a method for the syn-

Niementowski approach [3,27-30]:

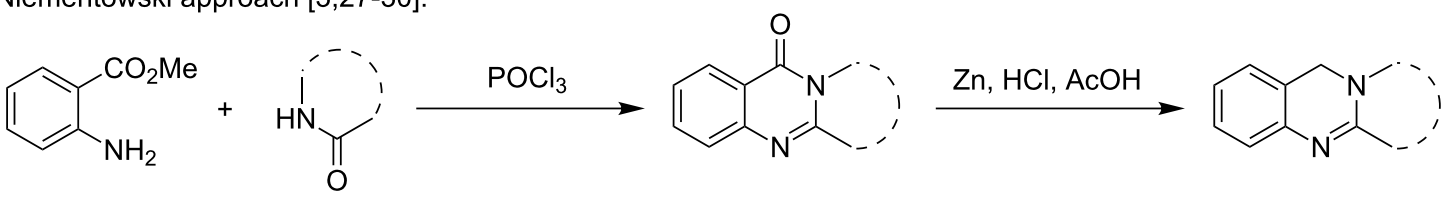

Han et al. [35]:

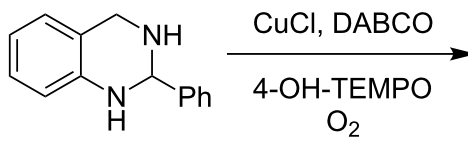<smiles>c1ccc(-c2ncc3ccccc3n2)cc1</smiles>

Reddy et al. [36]:<smiles>CC(C)=O</smiles>

This work:<smiles>Nc1ccccc1C=O</smiles><smiles>C1CCNCC1</smiles><smiles>CN1CCC2CN1Cc1ccccc1N2</smiles>

$\mathrm{Cu}(\mathrm{OAc})_{2} \cdot \mathrm{H}_{2} \mathrm{O}$

$\mathrm{AcOH}, \mathrm{O}_{2}, \mathrm{MeOH}$<smiles>c1ccc2c(c1)CN1C[IH]CCC1=N2</smiles>

$\mathrm{KI}, \mathrm{EtOH}$

TBHP

then, piperidine

Figure 2: Different approaches to the synthesis of quinazoline alkaloid structures 
thesis of dihydroquinazolines that would prevent further oxidation at the benzylic position. A factor complicating this effort was that dihydroquinazolines like deoxyvasicine (2) are known to auto-oxidize to their quinazolinone counterparts by exposure to air [3,45-47]. We initiated our efforts by exposing aminal 7 to stoichiometric amounts of $\mathrm{CuCl}_{2}$ in acetonitrile under a nitrogen atmosphere, which led to the formation of $\mathbf{2}$ in $81 \%$ yield (Table 1 , entry 1 ). To improve the efficiency of the process, catalytic conditions were subsequently evaluated. When aminal 7 was heated under reflux in an oxygen atmosphere and in the presence of $20 \mathrm{~mol} \%$ of $\mathrm{CuCl}_{2}, 2$ was only observed in trace amounts; deoxyvasicinone (4) and peroxide 8 were also formed as products. Switching the catalyst to $\mathrm{Cu}(\mathrm{OAc})_{2}$ led to a $15 \%$ yield of the desired product 2 , but the process was still unselective.

It appears that the first oxidation occurs exclusively at the aminal site to form deoxyvasicine (2). The presence of the amidine moiety apparently activates the molecule for oxidation at the benzylic position; we have observed that samples of aminal 7 can remain stable in the freezer for years, whereas 2 begins to convert to 4 within a day when exposed to atmospheric oxygen. Considering this, we reasoned that addition of a weak acid to protonate the relatively basic amidine moiety of $\mathbf{2}$ might deactivate the benzylic position toward oxidation while not interfering with the initial aminal oxidation. Indeed, using 1.1 equivalents of acetic acid as an additive with catalytic $\mathrm{Cu}(\mathrm{OAc})_{2}$ in acetonitrile led to the formation of 2 in $53 \%$ yield without formation of $\mathbf{4}$ and $\mathbf{8}$ (Table 1, entry 4). A simple change of the solvent from acetonitrile to methanol drastically improved the yield of 2 to $81 \%$ (Table 1, entry 5). A number of different copper salts, solvents and acids were then evaluated, but none of the changes led to a further improvement in yield. It appears that under certain conditions catalyst deactivation via copper oxide formation decreased the catalyst turnover and consequently product yields.

Table 1: Optimization of conditions for deoxyvasicine (2) formation. ${ }^{a}$<smiles>c1ccc2c(c1)CN1CCCC1N2</smiles>

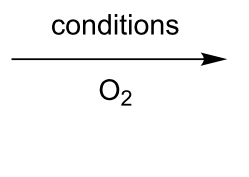<smiles>c1ccc2c(c1)CN1CCCC1=N2</smiles>

2<smiles>O=c1c2ccccc2nc2n1CCC2</smiles>

4<smiles>OOC1c2ccccc2N=C2CCCN21</smiles>

8

\begin{tabular}{|c|c|c|c|c|c|c|c|c|}
\hline Entry & Solvent (0.2 M) & Catalyst (mol \%) & Acid (equiv) & Temp. $\left({ }^{\circ} \mathrm{C}\right)$ & Time $(\mathrm{h})$ & Yield of $2(\%)$ & Yield of 4 (\%) & Yield of $8(\%)$ \\
\hline $1^{b}$ & $\mathrm{MeCN}$ & $\mathrm{CuCl}_{2} \cdot 2 \mathrm{H}_{2} \mathrm{O}(100)$ & - & $\mathrm{rt}$ & 6 & 81 & - & - \\
\hline 2 & $\mathrm{MeCN}$ & $\mathrm{CuCl}_{2} \cdot 2 \mathrm{H}_{2} \mathrm{O}(20)$ & - & 81 & 2 & trace & 14 & 10 \\
\hline 3 & $\mathrm{MeCN}$ & $\begin{array}{l}\mathrm{Cu}(\mathrm{OAc})_{2} \cdot \mathrm{H}_{2} \mathrm{O} \\
(20)\end{array}$ & - & 81 & 3 & 15 & 17 & trace \\
\hline 4 & $\mathrm{MeCN}$ & $\begin{array}{l}\mathrm{Cu}(\mathrm{OAc})_{2} \cdot \mathrm{H}_{2} \mathrm{O} \\
(20)\end{array}$ & $\mathrm{AcOH}(1.1)$ & 81 & 3 & 53 & - & - \\
\hline 5 & $\mathrm{MeOH}$ & $\begin{array}{l}\mathrm{Cu}(\mathrm{OAc})_{2} \cdot \mathrm{H}_{2} \mathrm{O} \\
(20)\end{array}$ & $\mathrm{AcOH}(1.1)$ & 65 & 4 & 81 & - & - \\
\hline 6 & $\mathrm{MeOH}$ & $\begin{array}{l}\mathrm{Cu}(\mathrm{OAc})_{2} \cdot \mathrm{H}_{2} \mathrm{O} \\
(20)\end{array}$ & - & 65 & 4 & 33 & 6 & 24 \\
\hline 7 & $\mathrm{AcOH}$ & $\begin{array}{l}\mathrm{Cu}(\mathrm{OAc})_{2} \cdot \mathrm{H}_{2} \mathrm{O} \\
(20)\end{array}$ & - & 80 & 24 & $18^{c}$ & - & - \\
\hline 8 & DMF & $\begin{array}{l}\mathrm{Cu}(\mathrm{OAc})_{2} \cdot \mathrm{H}_{2} \mathrm{O} \\
(20)\end{array}$ & $\mathrm{AcOH}(1.1)$ & 80 & 4 & 17 & 20 & - \\
\hline 9 & $\mathrm{MeOH}$ & $\mathrm{Cu}(2-\mathrm{EH})_{2}(20)$ & 2-EHA (1.1) & 65 & 12 & 71 & - & - \\
\hline 10 & $\mathrm{MeOH}$ & CuBr (20) & $\mathrm{AcOH}(1.1)$ & 65 & 8 & 72 & - & - \\
\hline 11 & $\mathrm{EtOH}^{\mathrm{d}}$ & $\begin{array}{l}\mathrm{Cu}(\mathrm{OAc})_{2} \cdot \mathrm{H}_{2} \mathrm{O} \\
(20)\end{array}$ & $\mathrm{AcOH}(1.1)$ & 78 & 1.5 & 73 & - & trace \\
\hline 12 & $\mathrm{MeOH}$ & $\begin{array}{l}\mathrm{Cu}(\mathrm{OAc})_{2} \cdot \mathrm{H}_{2} \mathrm{O} \\
(10)\end{array}$ & $\mathrm{AcOH}(1.1)$ & 65 & 18 & 67 & - & trace \\
\hline 13 & $\mathrm{MeOH}$ & $\begin{array}{l}\mathrm{Cu}(\mathrm{OAc})_{2} \cdot \mathrm{H}_{2} \mathrm{O} \\
(20)\end{array}$ & $\mathrm{AcOH}(1.1)$ & 40 & 24 & 61 & trace & trace \\
\hline 14 & $\mathrm{MeOH}$ & $\mathrm{Cu}(\mathrm{acac})_{2}(10)$ & $\mathrm{AcOH}(1.1)$ & 65 & 24 & $68^{c}$ & trace & trace \\
\hline
\end{tabular}

aReactions were performed on a $0.25 \mathrm{mmol}$ scale. $\mathrm{Cu}(2-\mathrm{EH})_{2}=$ copper(II) 2-ethylhexanoate. 2-EHA = 2-ethylhexanoic acid. ${ }^{\mathrm{b}} \mathrm{Nitrogen}$ atmosphere cThe reaction was incomplete. ${ }^{\mathrm{d}} 95 \%$ Solution. 
Using the optimized reaction conditions, a range of different aminals were selectively oxidized to the corresponding dihydroquinazolines (Table 2). In general, these products were obtained in moderate to good yields. Product 10, containing a piperidine ring, required a higher reaction temperature and resulted in a lower yield than the corresponding pyrrolidine and azepane products ( 2 and 12, respectively). While differences in conformation may in part account for the observed differences in reactivity (X-ray crystal structures of aminals containing pyrrol- idine and piperidine revealed that the pyrrolidine-containing aminal adopts a bent structure, whereas the piperidine aminal appears relatively strain-free [34]), this finding likely relates to the reduced propensity of six-membered rings to engage in reactions that form exocyclic double bonds. The isolation of azepinoquinazoline $\mathbf{1 2}$ in 73\% yield was gratifying but somewhat unexpected since Decker reported that samples of the compound completely oxidized to quinazolinone $\mathbf{2 3}$ when exposed to air for $24 \mathrm{~h} \mathrm{[3]}$. This demonstrates the need for

Table 2: Scope of the copper-catalyzed conversion of aminals to dihydroquinazolines. ${ }^{a}$
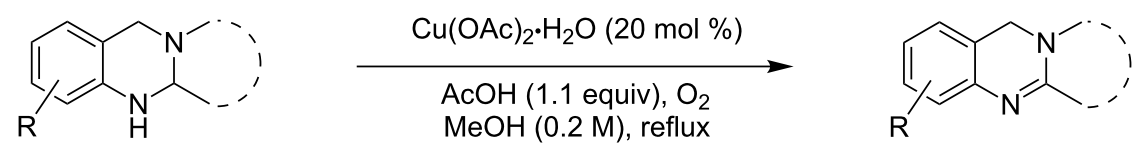

\begin{tabular}{|c|c|c|c|c|}
\hline Entry & Starting material & Product & Time (h) & Yield (\%) \\
\hline 1 & 7 & 2 & 7 & 86 \\
\hline $2^{b, c}$ & 9 & 10 & 8 & 57 \\
\hline $3^{c}$ & 11 & 12 & 7 & 73 \\
\hline 4 & 13 & 14 & 24 & 72 \\
\hline 5 & 15 & 16 & 8 & 82 \\
\hline 6 & 17 & 18 & 4 & 47 \\
\hline $7^{b, d}$ & $\begin{array}{l}\mathrm{Br} \\
19\end{array}$ & $\begin{array}{l}\mathrm{Br} \\
20\end{array}$ & 72 & 18 \\
\hline
\end{tabular}

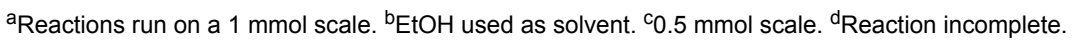


acetic acid to protonate the amidine, preventing further oxidation. While product $\mathbf{1 6}$ was obtained in good yields from tetrahydroisoquinoline-aminal $\mathbf{1 5}$, rutaecarpane-derived product 18 was formed in only $47 \%$ yield, apparently due to unidentified side-reactions. The reaction leading to the synthesis of the dibromo- analogue of deoxyvasicine 20, even under elevated temperature and extended reaction time, still did not reach completion after 3 days. The attenuated reactivity of aminal 19 is most likely the result of the decreased electron density on the anilinic nitrogen.

\section{KI-catalyzed oxidations of aminals to quina- zolinones}

Different conditions for the direct catalytic oxidation of aminals to quinazolinones were also explored. The use of $\mathrm{Cu}(\mathrm{OAc})_{2}$ and methanol, while appropriate for furnishing deoxyvasicine (2) from aminal 7, did not result in satisfactory yields of deoxyvasicinone (4, Table 1). Attempts to use other copper(I) or copper(II) salts and solvents under oxygen without the addition of acid to promote the full oxidation of aminal $\mathbf{2 1}$ to deoxyvasicinone (4) were met with disappointment, with yields of $\mathbf{4}$ for these conditions reaching a maximum of around $40 \%$ (Table 3 ). In most cases, peroxide $\mathbf{8}$ was observed as a major side product.
The $\mathrm{Cu} / \mathrm{TEMPO} / \mathrm{DABCO}$ catalyst system employed by Han et al. [35] for the oxidation of aminals to quinazolines provided an increased yield of 50\% (Table 3, entry 9). The best yields were obtained by using the conditions developed by Reddy and co-workers [36], namely the combined use of catalytic amounts of potassium iodide ( $20 \mathrm{~mol} \%$ ) and excess TBHP (5 equiv), followed by the addition of piperidine. In this instance, deoxyvasicinone was isolated in $80 \%$ yield (Table 3 , entry 12 ). In the course of this reaction, the TBHP adduct $\mathbf{2 2}$ is formed as an intermediate that is subsequently converted to the quinazolinone upon addition of piperidine. A slight modification of Reddy's conditions, in which piperidine was added directly to the solution after 36 hours instead of the removal of solvent from the intermediate peroxide beforehand, resulted in identical yields.

Using the optimized conditions, a range of different quinazolinones were synthesized (Table 4). In general, yields were moderate to good for substrates with varying ring sizes. In this manner the natural products deoxyvasicine (4), mackinazolinone (5) and rutaecarpine (6) were prepared, in addition to the azepinoquinazolone $\mathbf{2 3}$, which has been demonstrated to be a more effective antitussive agent than codeine [48]. Dibromo-

Table 3: Optimization of conditions for deoxyvasicinone (4) formation. ${ }^{a}$<smiles>c1ccc2c(c1)CN1CCCC1N2</smiles>

21

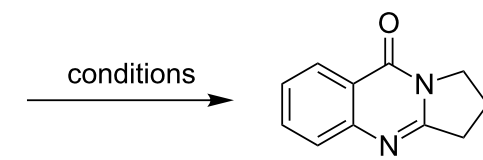

4

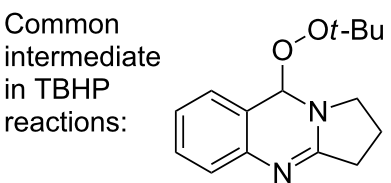

22

\begin{tabular}{|c|c|c|c|c|c|c|c|}
\hline Entry & Solvent $(0.2 \mathrm{M})$ & Catalyst (mol \%) & Oxidant (equiv) & Additive (equiv) & Temp. $\left({ }^{\circ} \mathrm{C}\right)$ & Time $(\mathrm{h})$ & Yield of $4(\%)$ \\
\hline 1 & DMSO & CuBr (20) & $\mathrm{O}_{2}$ & - & 100 & 2 & 21 \\
\hline 2 & DMSO & $\mathrm{CuBr}(20)$ & $\mathrm{O}_{2}$ & DBU $(0.4)$ & 100 & 17 & 25 \\
\hline 3 & DMSO & CuBr (20) & $\mathrm{O}_{2}$ & $\mathrm{DBU}(2)$ & 100 & 3 & 22 \\
\hline 4 & DMSO & CuBr (20) & $\mathrm{O}_{2}$ & - & 60 & 3 & 28 \\
\hline 5 & $\mathrm{MeCN}$ & $\mathrm{CuBr}(10)$ & $\mathrm{O}_{2}$ & - & 80 & 24 & 43 \\
\hline 6 & DMF & $\mathrm{CuBr}(10)$ & $\mathrm{O}_{2}$ & - & 80 & 24 & 42 \\
\hline 7 & DMSO & Cul (20) & $\mathrm{O}_{2}$ & - & 60 & 3 & 29 \\
\hline 8 & $\mathrm{MeCN}$ & $\mathrm{CuCl}_{2} \cdot 2 \mathrm{H}_{2} \mathrm{O}(20)$ & $\mathrm{O}_{2}$ & - & 50 & 5 & 19 \\
\hline 9 & $\mathrm{MeCN}$ & $\mathrm{CuCl}(10)$ & $\mathrm{O}_{2}$ & $\begin{array}{l}\text { DABCO }(0.1) \\
\text { TEMPO }(0.05)\end{array}$ & 80 & 12 & 50 \\
\hline 10 & DMSO & CuCl (10) & $\mathrm{O}_{2}$ & $\begin{array}{l}\text { DABCO }(0.1) \\
\text { TEMPO }(0.05)\end{array}$ & 100 & 3 & 38 \\
\hline 11 & PhMe & CuBr (20) & TBHP (5) & piperidine $^{b}(5)$ & $\mathrm{rt}$ & 0.5 & 61 \\
\hline 12 & $\mathrm{EtOH}$ & KI (20) & TBHP (5) & piperidine $^{b}(5)$ & $\mathrm{rt}$ & 36 & 80 \\
\hline
\end{tabular}

${ }^{a}$ Reactions run on a $0.25 \mathrm{mmol}$ scale. DBU = 1,8-Diazabicyclo[5.4.0]undec-7-ene. DABCO = 1,4-Diazabicyclo[2.2.2]octane. TEMPO = 2,2,6,6Tetramethylpiperidine-1-oxy radical. biperidine was added at the end of the reaction and the reaction mixture was heated at $50{ }^{\circ} \mathrm{C}$ for $1 \mathrm{~h}$. 
Table 4: Scope of Kl-catalyzed conversion of aminals to quinazolinones. ${ }^{a}$

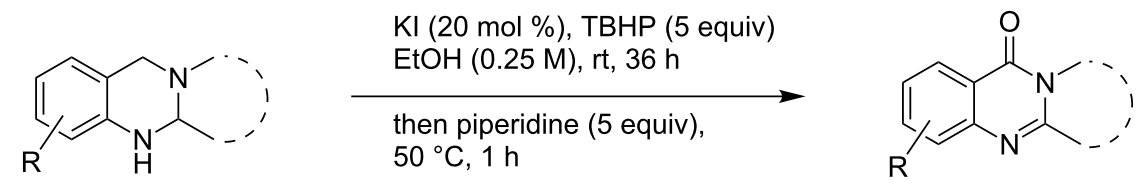

\begin{tabular}{|c|c|c|c|}
\hline Entry & Starting material & Product & Yield [\%] \\
\hline 1 & 7 & 4 & 84 \\
\hline $2^{b}$ & 9 & 5 & 59 \\
\hline $3^{b}$ & 11 & 23 & 69 \\
\hline 4 & 15 & 24 & 60 \\
\hline 5 & 17 & 6 & 58 \\
\hline 6 & 19 & 25 & 88 \\
\hline 7 & 26 & $\begin{array}{l}\mathrm{Br} \\
27\end{array}$ & 50 \\
\hline
\end{tabular}

aReactions run on a $1 \mathrm{mmol}$ scale. ${ }^{\mathrm{b}} 0.5 \mathrm{mmol}$ scale.

deoxyvasicinone analogue $\mathbf{2 5}$ was obtained in relatively high yield (88\%) whereas the corresponding analogue of mackinazolinone (27) was obtained in only $50 \%$ yield.
Interestingly, when quaternary aminal $\mathbf{2 8}$ was subjected to oxidative conditions in an attempt to prepare compound $\mathbf{2 9}$, deoxyvasicinone (4) was obtained as the major product in a 
process that involved demethylation (Scheme 1, reaction 1). The demethylation of aminals has been previously reported in cases where the product achieves aromaticity [49-51], which is presumably the driving force for this transformation. Aminal 30, which contains two tertiary amines and is readily obtainable by an acid-promoted hydride shift process [52-54], was also exposed to oxidative conditions (Scheme 1, reaction 2). We had hypothesized that quinazolinone $\mathbf{3 2}$ might be formed in this reaction by the debenzylation of an intermediate iminium ion. However, the major product from this reaction was identified to be 31, the apparent product of iminium hydrolysis.

\section{Conclusion}

We have demonstrated that quinazoline alkaloids and their analogues can be synthesized from aminals by using $\mathrm{Cu}(\mathrm{OAc})_{2} /$ $\mathrm{O}_{2} / \mathrm{AcOH}$ and KI/TBHP catalyst systems. The use of acetic acid in addition to oxygen and catalytic copper(II) salts was determined to prevent overoxidation of dihydroquinazolines, allowing access to these structures under mild conditions. A number of natural products and their analogues were obtainable by these methods, which should facilitate the preparation of novel materials for biological studies.

\section{Supporting Information}

\section{Supporting Information File 1}

Experimental details, characterization data and ${ }^{1} \mathrm{H}$ and

${ }^{13} \mathrm{C}$ NMR spectra for all new compounds.

[http://www.beilstein-journals.org/bjoc/content/ supplementary/1860-5397-9-135-S1.pdf]

\section{Acknowledgements}

Financial support from the NIH-NIGMS (grant R01GM101389-01) is gratefully acknowledged.

\section{References}

1. D'yakonov, A. L.; Telezhenetskaya, M. V. Chem. Nat. Compd. 1997, 33, 221. doi:10.1007/BF02234869

2. Sheu, J.-R. Cardiovasc. Drug Rev. 1999, 17, 237. doi:10.1111/j.1527-3466.1999.tb00017.x

3. Decker, M. Eur. J. Med. Chem. 2005, 40, 305. doi:10.1016/j.ejmech.2004.12.003

4. Rachana, S.; Ujata, B.; Mamta, P.; Priyanka, K. M.; Sonam, S. Indo Global J. Pharm. Sci. 2011, 1, 85.

5. Nepali, K.; Sharma, S.; Ojha, R.; Dhar, K. L. Med. Chem. Res. 2013, 22, 1. doi:10.1007/s00044-012-0002-5

6. Jia, S.; Hu, C. Molecules 2010, 15, 1873. doi:10.3390/molecules15031873

7. Dhankhar, S.; Kaur, R.; Ruhil, S.; Balhara, M.; Dhankhar, S.; Chhillar, A. K. Afr. J. Plant Sci. 2011, 5, 620.

8. Corrêa, G. M.; Alcântara, A. F. de C. Rev. Bras. Farmacogn. 2012, 22, 220. doi:10.1590/S0102-695X2011005000196

9. Asgarpanah, J.; Ramezanloo, F. Afr. J. Pharm. Pharmacol. 2012, 6, 1573.

10. Hooper, D. Pharm. J. Trans. 1888, 18, 841.

11. Bergman, J.; Bergman, S. Heterocycles 1981, 16, 347. doi:10.3987/R-1981-03-0347

12. Mhaske, S. B.; Argade, N. P. J. Org. Chem. 2001, 66, 9038. doi:10.1021/jo010727।

13. Yadav, J. S.; Reddy, B. V. S. Tetrahedron Lett. 2002, 43, 1905. doi:10.1016/S0040-4039(02)00135-1

14. Mhaske, S. B.; Argade, N. P. Tetrahedron 2006, 62, 9787. doi:10.1016/j.tet.2006.07.098

15. Bowman, W. R.; Elsegood, M. R. J.; Stein, T.; Weaver, G. W. Org. Biomol. Chem. 2007, 5, 103. doi:10.1039/b614075k<smiles>CC12CCCN1Cc1ccccc1N2</smiles>

28

$1 \mathrm{mmol}$<smiles>c1ccc(CN2Cc3ccccc3N3CCc4ccccc4C23)cc1</smiles>

$\mathrm{KI}(20 \mathrm{~mol} \%)$, TBHP (5 equiv) $\mathrm{EtOH}(0.25 \mathrm{M}), \mathrm{rt}, 36 \mathrm{~h}$

then piperidine ( 5 equiv)

$50^{\circ} \mathrm{C}, 1 \mathrm{~h}$

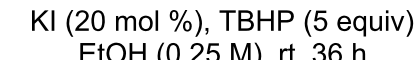
$\mathrm{EtOH}(0.25 \mathrm{M}), \mathrm{rt}, 36 \mathrm{~h}$

then piperidine ( 5 equiv), $50^{\circ} \mathrm{C}, 1 \mathrm{~h}$
30

$1 \mathrm{mmol}$<smiles>O=c1c2ccccc2nc2n1CCC2</smiles>

4

$40 \%$<smiles>O=C1c2ccccc2CCN1c1ccccc1CNCc1ccccc1</smiles>

31

$48 \%$<smiles>CC12CCCN1C(=O)c1ccccc1N2</smiles>

29

not observed<smiles>O=c1nc2n(c3ccccc13)CCc1ccccc1-2</smiles>

32

not observed 
16. Zhou, J.; Fu, L.; Lv, M.; Liu, J.; Pei, D.; Ding, K. Synthesis 2008, 3974. doi:10.1055/s-0028-1083245

17. Kraus, G. A.; Guo, H. J. Org. Chem. 2009, 74, 5337. doi:10.1021/jo900718g

18. Giri, R.; Lam, J. K.; Yu, J.-Q. J. Am. Chem. Soc. 2010, 132, 686. doi:10.1021/ja9077705

19. Kshirsagar, U. A.; Puranik, V. G.; Argade, N. P. J. Org. Chem. 2010, 75, 2702. doi:10.1021/jo100400z

20. Dabiri, M.; Salehi, P.; Bahramnejad, M.; Alizadeh, M. Monatsh. Chem. 2010, 141, 877. doi:10.1007/s00706-010-0341-1

21.Zeng, F.; Alper, H. Org. Lett. 2010, 12, 3642. doi:10.1021/ol101428v

22. Kshirsagar, U. A.; Argade, N. P. Org. Lett. 2010, 12, 3716. doi:10.1021/ol101597p

23. Tseng, M.-C.; Cheng, H.-T.; Shen, M.-J.; Chu, Y.-H. Org. Lett. 2011, 13, 4434. doi:10.1021/ol201793v

24. Granger, B. A.; Kaneda, K.; Martin, S. F. Org. Lett. 2011, 13, 4542. doi:10.1021/ol201739u

25. Fang, J.; Zhou, J. Org. Biomol. Chem. 2012, 10, 2389. doi:10.1039/c2ob07178a

26. Murai, K.; Komatsu, H.; Nagao, R.; Fujioka, H. Org. Lett. 2012, 14, 772. doi:10.1021/ol203313n

27. von Niementowski, S. J. Prakt. Chem. 1895, 51, 564. doi:10.1002/prac.18950510150

28. Pachter, I.; Suld, G. J. Org. Chem. 1960, 25, 1680. doi:10.1021/jo01079a615

29. D'yakonov, A. L.; Telezhenetskaya, M. V.; Yunusov, L. Yu. Chem. Nat. Compd. 1986, 22, 435. doi:10.1007/BF00579819

30. Lee, E. S.; Park, J.-G.; Jahng, Y. Tetrahedron Lett. 2003, 44, 1883. doi:10.1016/S0040-4039(03)00080-7

31.Zhang, C.; De, C. K.; Mal, R.; Seidel, D. J. Am. Chem. Soc. 2008, 130, 416. doi:10.1021/ja077473r

32. Dieckmann, A.; Richers, M. T.; Platonova, A. Yu.; Zhang, C.; Seidel, D.; Houk, K. N. J. Org. Chem. 2013, 78, 4132. doi:10.1021/j0400483h

33. Zhang, C.; De, C. K.; Seidel, D. Org. Synth. 2012, 89, 274.

34. Richers, M. T.; Deb, I.; Platonova, A. Y.; Zhang, C.; Seidel, D. Synthesis 2013, 45, 1730-1748. doi:10.1055/s-0033-1338852

35. Han, B.; Yang, X.-L.; Wang, C.; Bai, Y.-W.; Pan, T.-C.; Chen, X.; Yu, W. J. Org. Chem. 2012, 77, 1136. doi:10.1021/jo2020399

36. Kumar, R. A.; Maheswari, C. U.; Ghantasala, S.; Jyothi, C.; Reddy, K. R. Adv. Synth. Catal. 2011, 353, 401. doi:10.1002/adsc.201000580

37. Kumar, R. A.; Saidulu, G.; Prasad, K. R.; Kumar, G. S.; Sridhar, B.; Reddy, K. R. Adv. Synth. Catal. 2012, 354, 2985. doi:10.1002/adsc.201200679

38. Li, C.-J. Acc. Chem. Res. 2009, 42, 335. doi:10.1021/ar800164n

39. Punniyamurthy, T.; Rout, L. Coord. Chem. Rev. 2008, 252, 134. doi:10.1016/j.ccr.2007.04.003

40. Wendlandt, A. E.; Suess, A. M.; Stahl, S. S. Angew. Chem., Int. Ed. 2011, 50, 11062. doi:10.1002/anie.201103945

41. Hirano, K.; Miura, M. Chem. Commun. 2012, 48, 10704. doi:10.1039/c2cc34659a

42. Zhang, C.; Tang, C.; Jiao, N. Chem. Soc. Rev. 2012, 41, 3464. doi:10.1039/c2cs15323h

43. Jones, K. M.; Klussmann, M. Synlett 2012, 159. doi:10.1055/s-0031-1290117

44. Ratnikov, M. O.; Doyle, M. P. J. Am. Chem. Soc. 2013, 135, 1549. doi:10.1021/ja3113559

45. Mehta, D. R.; Naravane, J. S.; Desai, R. M. J. Org. Chem. 1963, 28 , 445. doi:10.1021/jo01037a041
46. Johns, S. R.; Lamberton, J. A.; Suares, H. Aust. J. Chem. 1985, 38, 1007. doi:10.1071/CH9851007

47. Nakagawa, Y.; Stevens, R. V. J. Org. Chem. 1988, 53, 1873. doi:10.1021/jo00244a007

48. Nepali, K.; Bande, M. S.; Sapra, S.; Garg, A.; Kumar, S.; Sharma, P.; Goyal, R.; Satti, N. K.; Suri, O. P.; Dhar, K. L. Med. Chem. Res. 2012, 21, 1271. doi:10.1007/s00044-011-9641-1

49. Elderfield, R. C.; Kreysa, F. J.; Dunn, J. H.; Humphreys, D. D. J. Am. Chem. Soc. 1947, 69, 186. doi:10.1021/ja01193a506

50. Yamazaki, C. J. Org. Chem. 1981, 46, 3956. doi:10.1021/jo00333a005

51. Schulze, K.; Richter, C.; Ludwig, R. Tetrahedron Lett. 1989, 30, 2369. doi:10.1016/S0040-4039(01)80401-9

52. Zhang, C.; Murarka, S.; Seidel, D. J. Org. Chem. 2009, 74, 419. doi:10.1021/j0802325x

53. Mori, K.; Ohshima, Y.; Ehara, K.; Akiyama, T. Chem. Lett. 2009, 38, 524. doi:10.1246/cl.2009.524

54. He, Y.-P.; Du, Y.-L.; Luo, S.-W.; Gong, L.-Z. Tetrahedron Lett. 2011, 52, 7064. doi:10.1016/j.tetlet.2011.10.062

\section{License and Terms}

This is an Open Access article under the terms of the Creative Commons Attribution License (http://creativecommons.org/licenses/by/2.0), which permits unrestricted use, distribution, and reproduction in any medium, provided the original work is properly cited.

The license is subject to the Beilstein Journal of Organic Chemistry terms and conditions:

(http://www.beilstein-journals.org/bjoc)

The definitive version of this article is the electronic one which can be found at: doi:10.3762/bjoc. 9.135 